Nursing News: Jurnal Ilmiah Keperawatan Vol 5, No 2 Tahun 2021 ,hal 75-85

Tersedia online di https://publikasi.unitri.ac.id/index.php/fikes ISSN 2527-9823(online)

\title{
ANALISA KORELASIONAL POLA ASUH PERMISIF ORANGTUA TERHADAP EFIKASI DIRI ANAK USIA SEKOLAH DAN REMAJA DI RT 03/ RW 02 DESA LANDUNGSARI KABUPATEN MALANG
}

\author{
Hilda Mazarina Devi ${ }^{1}$, Rona Sari Mahaji Putri ${ }^{2}$ \\ ${ }^{1,2)}$ Fakultas Ilmu Kesehatan, Universitas Tribhuwana Tunggadewi, Malang \\ email: hilda.mazarina@unitri.ac.id; ronasari@unitri.ac.id
}

\begin{abstract}
Self efficacy is an individual belief on personal ability to perform certain behaviors. The disadvantages of performing permissive parenting on children, they often to take an action without control, tend to be aggressive, and failed to stabilize the negative emotions. The aim of this study was to determine the relationship between permissive parenting and self-efficacy in school-aged children. The research design was correlational descriptive with cross-sectional apprach. The population of this study were all parents who have children aged 6-18 years old. Sampling method was taken by simple random sampling. Spearman Rank Correlation Test used for data analysis. The results showed there is a negative relationship between permissive parenting and self efficacy among school aged children ( $p$ value $\leq 0.05 ; r=$ 0.845 ), indicating the more use of permissive parenting the lower the self-efficacy among children. It is recommended for parents to use properparenting to increases the children self $\sim$ efficacy academically and non $\sim$ academically.
\end{abstract}

Keywords: Children; parents; permissive parenting; self efficacy

\begin{abstract}
ABSTRAK
Efikasi diri merupakan keyakinan personal yang kuat dalam mengerjakan sebuah perilaku. Dalam tumbuh kembang anak, penerapan pola asuh pernisif berdampak pada munculnya perilaku ceroboh, agresivitas, serta ketidakmampuan mengontrol emosi dengan positif. Penelitian ini dilaksanakan untuk mengetahui hubungan pola asuh pemisif orangtua terhadap tingkat efikasi diri pada anak. Desain penelitian yang digunakan adalah deskriptif korelasional dengan pendekatan cross-sectional. Populasi dari penelitian ini adalah pasangan orangtua dan anak dengan rentang usia 6-18 tahun di wilayah RT 03/RW 02 Desa Landungsari, Kabupaten Malang. Sampel diambil dengan teknik simple random sampling berjumlah 30 pasang orangtua dan anak. Uji Korelasi Spearman Rank digunakan untuk menganalisis data. Hasil menunjukan adanya hubungan pola asuh permisif orangtua terhadap efikasi diri pada anak $(\phi=0.000 \leq 0,05 ; r=-0.845$ ). Hal ini bermakna semakin rendah pola asuh permisif pada orangtua maka semakin tinggi tingkat efikasi diri yang terjadi pada anak. Penetapan dan aplikasi pola asuh yang tepat bagi orangtua sangat disarankan untuk meningkatkan efikasi diri anak usia sekolah dan remaja dengan baik di bidang non-akademik maupun akademik.
\end{abstract}

Kata Kunci : Anak; Efikasi diri; Orangtua; Pola asuh permisif

Cara mengutip: Devi,HM., Putri,RSM.( 2021). Analisa Korelasional Pola Asuh Permisif Orangtua Terhadap Efikasi Diri Anak Usia Sekolah dan Remaja di RT 03/RW 02 Desa Landungsari Kabupaten Malang. Nursing News: Jurnal Ilmiah Keperawatan. Vol 5, No 2, 2021, hal 75-85. Retrieved from https://publikasi.unitri.ac.id/index.php/fikes/article/view/2305 


\section{PENDAHULUAN}

Mendapatkan pendidikan dan pola asuh terbaik dari orangtua merupakan hak bagi setiap anak. Terlebih dalam menghadapi berbagai tugas perkembangan semenjak anak usia sekolah hingga menginjak remaja (Mahardikawati, 2012). Anak usia sekolah akan dihadapkan pada berbagai perubahan perkembangan pada aspek fisik, kognitif, kepribadian, dan aspek sosial (Papalia, Olds dan Feldman, 2001). Ketika memasuki usia remaja, anak diharapkan untuk berkembang dan tidak lagi bertingkah seperti anak kecil, memiliki kemandirian yang meningkat, dan rasa tanggung jawab (Jahja, 2011).

Setiap orangtua memiliki perbedaan dalam cara mendidik anak. Pola asuh atau cara mendidik anak didefinisikan sebagai segala bentuk proses interaksi yang akan memberikan pengaruh terhadap perkembangan serta kepribadian anak (Irmawati, 2002). Gunarsa (2002) menyatakan bahwa pola asuh permisif memiliki karakteristik cara didik yang membebaskan anak, tidak adanya aturan yang mengikat, serta anak diberikan kesempatan untuk membuat keputusan bagi dirinya sendiri tanpa pertimbangan orangtua. Pola asuh ini berbeda dengan pola asuh acuh tak acuh/mengabaikan, pengajaran yang diberikan orangtua selama penerapan pola asuh permisif justru dapat membentuk kemandirian yang baik pada anak, sehingga secara bersama akan membentuk tingkat efikasi diri yang kuat dan baik (Wirawan, 2012). Di sisi lain, peran orangtua yang terlalu mengikuti keinginan anak akan menyebabkan anak kurang matang secara sosial dan kurang memiliki rasa percaya diri. Hal ini menjadi kekurangan pola asuh permisif.

Sebuah penelitian yang dilaksanakan dengan pengambilan data di berbagai kota besar Indonesia, sebanyak $51,7 \%$ orangtua menerapkan pola asuh yang tergolong baik dan selebihnya menerapkan pola asuh orangtua yang cenderung negatif (Fakhruddin, 2011). Lebih lanjut dalam penelitian tersebut juga ditemukan sebanyak $53.9 \%$ orangtua di Indonesia menerapkan pola asuh demokratis, $22.5 \%$ menerapkan pola asuh permisif, dan sisanya mendidik anak dengan cara otoriter (Fakhruddin, 2011). Hasil penelitian Nurhayanti dan Novotasari (2013) yang dilaksanakan pada kelompok siswa sekolah menengah atas menunjukan bahwa mayoritas siswa dididik dengan pola pengasuhan permisif $(\mathrm{N}=38 ; 43,1 \%)$. Penelitian lain terhadap 25 orang responden siswa menengah pertama, mayoritas orangtua menerapkan pola asuh permisif (84\%) (Purwaningsih dan Setyaningsih, 2015). Hasil penelitian Kurniawan (2017) yang dilakukan di lingkungan semi-urban juga menunjukan pola asuh permisif berpengaruh terhadap rasa percaya diri anak $(0.3 \%)$, sebanyak 55 siswa $(38 \%)$ memiliki tingkat percaya diri sangat tinggi, 81 siswa (55\%) masuk dalam kategori tinggi dan 10 siswa (7\%) masuk dalam kategori tingkat percaya diri yang sedang. Penelitian ini juga di dukung oleh penelitian Yusuf (2019) yang menunjukan bahwa ada hubungan yang sangat signifikan antra kepercayaan diri anak dengan penerapan pola asuh permisif. Pola asuh permisif menyumbang $36 \%$ efektivitas peningkatan kepercayaan diri (Yusuf, 2019).

Efikasi diri didefinisikan sebagai keyakinan personal untuk mampu mengendalikan fungsi personal terhadap berbagai kejadian atau stressor lingkungan (Feist dan Feist, 2008). Efikasi diri akan berkembang secara simultan seiring meningkatnya kemampuan anak dan bertambahnya berbagai pengalaman hidup. Efikasi diri secara langsung juga dapat berdampak pada pemilihan perilaku, usaha motivasi, dan daya tahan (Luthans dan Chaffin, 2021). Memiliki tingkat efikasi diri yang rendah terutama pada anak yang berusia sekolah akan menyebabkan timbulnya kecenderungan untuk menghindari tugas, ragu dan kurang percaya diri pada kemampuan personal, tugas yang sulit dipandang sebagai ancaman, lamban dalam membenahi diri ketika mendapat kegagalan, memiliki aspira 
dan komitmen pada tugas yang lemah, kurang memiliki analisis dalam problem-solving, serta rendahnya minat terhadap aktualisasi diri (Irsan, 2016).

Saraswati dan Ratnaningsih (2016) menyatakan, sebanyak 26,3\% efikasi diri pada seorang anak akan menyumbang kematangan akademik dan rasa percaya dirinya. Sedangkan hasil penelitian Suharto, Japlani dan Ali (2021), efikasi diri yang terbentuk dengan baik sejak anak dalam pengasuhan orangtua akan berpengaruh terhadap terhadap peningkatan motivasi ketika seorang anak menginjak pendidikan di perguruan tinggi hingga sebesar $50,2 \%$. Berdasarkan sebuah teori yang dikemukakan oleh Albert Bandura (2010) bahwa efikasi diri sangat dibutuhkan dalam berbagai bidang kehidupan. Kemudian apabila dikaitkan dengan teori Erikson (1994) mengenai perkembangan kepribadian manusia, efikasi diri dibutuhkan dalam menghadapi setiap tahap krisis psikososial untuk mencapai kematangan diri. Peranan mastery experience oleh orangtua juga sangat perlu diterapkan dalam pengasuhan anak (Bandura, 2010).

Berdasarkan pengambilan data awal di RT 03/ RW 02 Desa Landungsari Malang, pada tanggal 09 Februari 2021. Pengamatan dimulai dengan memperhatikan perilaku sekelompok anak usia sekolah yang sedang berinteraksi dengan teman sebaya di lingkungan. Hasil pengamatan menunjukan beberapa anak memiliki rasa keyakinan yang tinggi, dan berani bertanya meski sebagian anak-anak menunjukkan rasa kepercayaan diri yang kurang. Lebih lanjut ketika di wawancarai mengenai pola asuh orangtua, beberapa anak yang berusia lebih besar menyatakan orangtua sering mengajak berdiskusi dalam memutuskan hal yang berkaitan dengan masa depan anak, kebebasan mengatur waktu bermain dan belajar, orangtua juga selalu memberikan apa yang anak minta, dan jarang marah. Hal lain yang juga nampak ketika pengamatan adalah anak tidak malu dalam bersosialisasi dengan teman mainnya, anak mau bekerja sama dan berpartisipasi dalam kelompok. Selain itu, anak juga berani menyampaikan pendapatnya terhadap peneliti sebagai orang yang baru dikenal. Berdasarkan hasil pengamatan dan wawancara tersebut peneliti tertarik untuk menganalisis apakah terdapat hubungan antra pola asuh permisif terhadap efikasi diri pada anak. Tujuan penelitian untuk mengetahui apakah terdapat korelasi antra penerapan pola asuh permisif oleh orangtua terhadap tingkat efikasi diri pada anak yang berusia sekolah dan remaja.

\section{METODE PENELITIAN}

Penelitian ini merupakan cross-sectional study dengan penekanan pada sekali waktu pengambilan data. Populasi dalam penelitian ini sebanyak 60 orang. Subjek riset sebanyak 30 pasang orangtua bersama anak usia sekolah dan/atau remaja yang bertempat tinggal di wilayah Desa Landungsari RT 03/RW 02 Kabupaten Malang. Simple random sampling digunakan dalam penetapan sampel penelitian. Variabel penelitian terdiri atas dua, yaitu pola asuh permisif dan efikasi diri. Penelitian ini dilakukan pada bulan 1 Februari 2021 sampai 1 Maret 2021. Kriteria inklusi penelitian yakni orangtua yang memiliki anak berusia 5-15 tahun, serta yang menyetujui untuk menjadi responden dengan konfirmasi dalam informed consent. Data diperoleh mengunakan lembar kuesioner pola asuh permisif (Yusman, 2015) dengan indikator 17 pernyataan khusus orangtua berdasarkan teori bandura dengan hasil penilaian skor $60-79=$ pola asuh permisif, skor $42-59=$ pola asuh selain permisif. Efikasi diri pada anak dikaji dengan menggunakan kuesioner efikasi diri (Nuruddin, 2015) dengan indikator 26 pernyataan dengan hasil penilaian efikasi diri tinggi (skor 70-96), sedang (skor 43-69), dan rendah(skor16-42). 
Nursing News: Jurnal Ilmiah Keperawatan, Vol 5, No 2 Tahun 2021 ,hal 75-85

HASIL DAN PEMBAHASAN

Tabel. 1 Karakterstik Rsponden Anak

\begin{tabular}{|c|c|c|}
\hline Karakteristik & $\mathrm{F}$ & $\%$ \\
\hline \multicolumn{3}{|l|}{ Gender } \\
\hline Pria & 16 & 53 \\
\hline Wanita & 14 & 47 \\
\hline Jumlah & 30 & 100 \\
\hline \multicolumn{3}{|l|}{ Usia } \\
\hline 6-15 Tahun & 26 & 87 \\
\hline 16-25 Tahun & 4 & 13 \\
\hline Jumlah & 30 & 100 \\
\hline \multicolumn{3}{|l|}{ Pendidikan } \\
\hline SD & 15 & 50 \\
\hline SMP & 10 & 33 \\
\hline SMA & 5 & 17 \\
\hline Jumlah & 30 & 100 \\
\hline
\end{tabular}

Sebagian besar responden anak yang mengikuti penelitian adalah laki-laki (16 orang, $53 \%$ ), hampir seluruh responden berusia 5 sampai 15 tahun sebanyak 26 orang (87\%), setengah dari keseluruhan responden memiliki jenjang pendidikan SD sebanyak 15 orang $(50 \%)$.

Hampir seluruh orangtua responden yang mengikuti penelitian berjenis kelamin perempuan sebanyak 29 orang (97\%), sebagian besar orangtua responden berusia 20 sampai 39 tahun sebanyak 19 orang (63\%), sebagian besar orangtua responden memiliki tingkat pendidikan SMA/SMK sebanyak 16 orang $(53 \%)$, sebagian besar orangtua bekerja dalam ranah domestik (24 orang, 80\%), dan hampir seluruh orangtua responden berpendapatan $<1$ juta Rupiah sebanyak 24 orang $(80 \%)$.
Tabel. 2 Karakteristik Responden Orangtua

\begin{tabular}{|c|c|c|}
\hline Karakteristik & $\mathrm{f}$ & $\%$ \\
\hline \multicolumn{3}{|l|}{ Gender } \\
\hline Pria & 1 & 3 \\
\hline Wanita & 29 & 97 \\
\hline Jumlah & 30 & 100 \\
\hline \multicolumn{3}{|l|}{ Usia } \\
\hline 20-39 Tahun & 19 & 63 \\
\hline 40-59 Tahun & 10 & 33 \\
\hline 60-69 Tahun & 1 & 3 \\
\hline Jumlah & 30 & 100 \\
\hline \multicolumn{3}{|l|}{ Pendidikan Orangtua } \\
\hline SD & 7 & 23 \\
\hline SMP/SLTP & 6 & 20 \\
\hline SMA/SMK & 16 & 53 \\
\hline $\mathrm{S} 1$ & 1 & 3 \\
\hline Jumlah & 30 & 100 \\
\hline \multicolumn{3}{|l|}{ Pekerjaan Orangtua } \\
\hline IRT & 24 & 80 \\
\hline Buruh Pabrik & 2 & 7 \\
\hline Wiraswasta & 1 & 3 \\
\hline Swasta & 3 & 10 \\
\hline Jumlah & 30 & 100 \\
\hline \multicolumn{3}{|c|}{ Pendapatan Orangtua } \\
\hline$<1 \mathrm{JT}$ & 24 & 80 \\
\hline$>1 \mathrm{JT}$ & 6 & 20 \\
\hline Jumlah & 30 & 100 \\
\hline
\end{tabular}

Tabel 3. Tabulasi silang pola asuh pada orangtua dan efikasi diri anak $(\mathrm{N}=30)$.

\begin{tabular}{ccccc}
\hline \multicolumn{5}{c}{ Pola Asuh Orangtua } \\
\hline Efikasi diri & $\mathrm{P}$ & $\neq \mathrm{P}$ & $\mathrm{f}$ & $\%$ \\
\hline Tinggi & 3 & 1 & 4 & 13 \\
\hline Sedang & 6 & 4 & 10 & 33 \\
\hline Rendah & 12 & 4 & 16 & 54 \\
\hline & 16 & 14 & 30 & 100 \\
\hline
\end{tabular}

$\mathrm{P}$ : Permisif; $\neq \mathrm{P}$ : Selain Permisif

Tabel 3 menunjukkan orangtua yang mengunakan pola asuh permisif sebanyak 16 orang $(54 \%)$, dan mayoritas responden anak 
Nursing News: Jurnal Ilmiah Keperawatan, Vol 5, No 2 Tahun 2021 ,hal 75-85

memiliki tingkat efikasi diri dalam kategori

Tabel 4. Hasil Analisa Statistik Hubungan Pola Asuh Permisif dan Efikasi diri anak.

\begin{tabular}{lccc}
\hline & $\begin{array}{c}\text { Jumlah } \\
\text { Sampel }\end{array}$ & Nilai $(r)$ & $\begin{array}{c}\text { Nilai } \\
(p)\end{array}$ \\
\hline Spearman's rho & 60 & $r=-, 845^{* *}$ & $p=, 000$ \\
\hline
\end{tabular}

Berdasarkan Tabel 4 diketahui hasil Uji Spearman Rank diperoleh nilai signifikansi sebesar 0,000 ( $\mathrm{p}$ value $\leq 0,05$ ) yang berarti ada hubungan pola asuh permisif orangtua terhadap efikasi diri pada anak. Nilai koefisien korelasi sebesar -0,845 menunjukan kuat korelasi yang baik dan berarah negatif. Hal ini bermakna semakin rendahnya penerapan pola asuh permisif orangtua maka semakin tinggi tingkat efikasi diri yang terjadi pada remaja.

\section{PEMBAHASAN}

\section{Karakteristik Responden Orangtua}

Tabel 3 diketahui sebagian besar orangtua responden mengunakan pola asuh permisif sebanyak 16 orang (53\%) dan hampir setengah orangtua mengunakan pola asuh selain permisif sebanyak 14 orang (47\%). Penerapan pola asuh permisif memiliki efek negatif yang dapat menyebabkan anak melakukan apa saja yang mereka inginkan, anak-anak cenderung tidak pernah belajar untuk mengendalikan perilaku, dam selalu mengharap setiap kemauan anak untuk dituruti. Anak juga akan memiliki pengendalian diri serta efikasi diri yang rendah, terlalu bebas, memanjakan anak, dan tidak adanya kontrol dari orangtua jika anak melakukan perilaku negatif dan menyimpang dari perilaku normal seusianya. Beberapa sikap negatif seperti agresif dan impulsif, pembangkang, bingung dalam penentuan masa depan dan cita-cita, serta memiliki prestasi rendah dapat terbentuk dari penerapan pola asuh permisif (Santrock, 2002). rendah sebanyak 16 orang (54\%). Berdasarkan karakteristik jenis kelamin orangtua menunjukkan bahwa hampir seluruh orangtua responden berjenis kelamin perempuan (29 orang, 97\%). Menurut Hurlock (2018) jenis kelamin menjadi faktor yang mempengaruhi pola asuh orangtua, karena seorang ibu pada umumnya lebih cenderung kurang otoriter, lebih membebaskan anak atau permisif dibandingkan dengan ayah.

Usia responden orangtua pada penelitian ini juga menjadi faktor yang diteliti dalam penerapan pola asuh, sebagian besar orangtua berusia muda yakni antra 20 sampai 39 tahun sebanyak 19 orang (63\%). Berdasarkan teori Hurlock (2018) usia orangtua menjadi salah satu faktor yang sangat berpengaruh terhadap pola asuh, karena dewasa muda cenderung lebih mengunakan pola asuh demokratis dan permisif bila dibandingkan dengan senior.

Pada faktor pendidikan, hasil menunjukkan mayoritas orangtua memiliki jenjang pendidikan SMA/SMK sebanyak 16 orang (53\%). Orangtua dengan tingkat pendidikan yang lebih tinggi memiliki banyak potensi untuk mendukung anak dalam belajar, beorientasi kerja, memiliki keyakinan terhadap kemampuan pengasuhan yang baik, dan orangtua yang berpendidikan tinggi mau memikirkan strategi efektif untuk membantu anak dibanding orangtua dengan riwayat pendidikan yang lebih rendah (Dasmo, Nurhayati, dan Marhento, 2014). Selaras dengan teori Hurlock (2018) yang menyatakan bahwa pendidikan orangtua menjadi faktor yang sangat mempengaruhi penerapan pola asuh. Orangtua dengan pendidikan tinggi, terlebih mau mengikuti berbagai kursus ataupun seminar pengasuhan anak cenderung mengunakan pola asuh authorirative dibandingkan dengan orangtua yang tidak mendapatkan pendidikan dan pelatihan dalam mengasuh anak. 
Hasil penelitian pada faktor pekerjaan, orangtua yang bekerja di ranah domestik yakni sebanyak 24 orang (80\%). Hadzic (2013) dalam penelitiannya menyimpulkan bahwa terdapat efek signifikan antra ibu yang bekerja terhadap perilaku anak. Lebih lanjut, peneliti juga menjelaskan bahwa setiap pekerjaan orangtua berdampak pada pola pengasuhan terhadap anak. Jam kerja yang panjang akan menyebabkan terbatasnya perhatian orangtua terhadap anak, menimbulkan pengawasan yang rendah. Berbanding terbalik dengan penelitian Widanarti (2002) yang menunjukkan bahwa tidak ada perbedaan efikasi diri anak terhadap jenis pekerjaan orangtua. Tingkat efikasi diri anak memiliki sedikit perbedaan berdasarkan jenis pekerjaan orangtua.

Berdasarkan besaran pendapatan, mayoritas orangtua memiliki gaji di bawa satu juta (24 orang, 80\%). Besaran gaji tersebut merupakan besaran gaji yang rendah dibandingkan dengan upah minimum Kota Malang (UMK) (Pemerintah Kota Malang, 2021). Orangtua yang berasal dari kelas ekonomi bawa sering menggunakan hukuman fisik, lebih otoriter, dan menunjukkan kekuatan terhadap anak bahkan pola asuh otoriter memiliki hubungan terhadap kenakalan remaja (Febrianti, 2012). Hal ini berbanding terbalik dengan hasil penelitian yang menunjukkan bahwa mayoritas orangtua responden memiliki pola asuh yang permisif. Latar belakang sosial ekonomi keluarga yang rendah akan menurunkan peluang bagi anak untuk mendapatkan dukungan orangtua yang lebih baik secara emosional dan instrumental. Selain itu kondisi sosial ekonomi keluarga yang kurang juga akan mempengaruhi penyediaan fasilitas belajar anak serta kesempatan yang dibutuhkan oleh anak dalam mengembangkan potensi dan prestasi anak termasuk pngembangan efikasi diri (Farisi, 2020).

\section{Karakteristik Responden Anak}

Berdasarkan Tabel 3 diketahui sebagian besar responden anak memiliki efikasi diri yang sebagai ibu rumah tangga menjadi mayoritas

rendah sebanyak 16 orang (53\%), hampir setengah responden memiliki efikasi sedang sebanyak 10 orang $(33 \%)$, dan sebagian kecil responden memiliki efikasi diri yang tinggi sebanyak 4 orang (13\%). Akibat dari efikasi yang rendah adalah anak ragu akan kemampuan personal, cenderung menjauhi penugasan yang sulit karena tugas tersebut dipandang sebagai ancaman. Anak dengan efikasi rendah juga memiliki aspirasi yang kurang baik, serta rendahnya komitmen dalam mencapai tujuan hidup. Ketika menghadapi tugas-tugas yang sulit, anak dengan efikasi diri yang rendah akan lebih memikirkan kekurangan-kekurangan diri, penyulit serta berbagai hal negatif yang dianggap mengancam (Adicondro dan Purnamasari, 2011).

Berdasarkan jenis kelamin didapatkan bahwa sebagian besar responden anak berjenis kelamin laki-laki sebanyak 16 orang (53\%). Baron, Robert, dan Bryne (2012) menyatakan bahwa dalam budaya tertentu, individu dengan peran gender laki-laki memiliki efikasi diri yang lebih tinggi dibandingkan dengan peran perempuan. Hasil penelitian berbanding terbalik dengan teori tersebut, sebanyak 16 anak laki-laki justru memiliki efikasi diri yang rendah dibandingkan dengan anak perempuan. Secara teori anak laki-laki memiliki harapan yang lebih tinggi terhadap kesuksesan pekerjaan dan menempatkan lebih banyak penekanan pada hasil dibandingkan anak perempuan (Hurlock, 2018).

Berdasarkan usia, didapatkan bahwa hampir seluruhnya responden berusia 6 sampai 15 tahun (26 orang, 87\%). Kemenkes RI (2018) menyatakan masa usia sekolah berlangsung antra usia $6-12$ tahun, kemudian remaja berlangsung antra umur $13-18$ tahun. Ketika melalui masa ini, selain menghadapi banyak perubahan secara biologis, pola pikir, dan kecerdasan sosioemosional, anak juga memiliki tugas untuk dapat melakukan perubahan personal sekaligus memenuhi 
tuntutan perubahan jaman. Hurlock (2018) bahkan menyatkan ketika memasuki masa masa pencarian jati diri dengan konsekuensi mudah menerima informasi dari lingkungan tanpa disertai pemikiran lebih lanjut. Penyesuaian diri pada masa usia sekolah hingga remaja juga menuntut kemampuan anak untuk hidup dan bergaul secara wajar. Anak yang puas terhadap capaian dirinya akan memiliki efikasi diri yang baik dan respon lingkungan yang baik. Hal ini menjadi jawaban mengapa lebih banyak responden anak memiliki efikasi diri yang rendah (16 orang, $54 \%)$.

Berdasarkan pendidikan anak, didapatkan bahwa setengah responden dijenjang SD (15 orang, 50\%). Berdasarkan penelitian Nurmalita, Yoenanto, dan Nurdibyanandaru (2021), pengalaman anak di sekolah akan membantunya dalam membentuk efikasi diri. Sekolah yang memiliki kualitas dan standar mutu yang baik memiliki pengaruh kuat terhadap prestasi-prestasi yang diraih oleh siswanya. Sekolah yang baik ditunjukkan dengan ritme belajar mengajar yang teratur, dipimpin oleh kepala sekolah yang aktif dan bersemangat, serta memiliki pendidik yang juga ikut andil dalam peran pengambil keputusan atau decision maker. Siswa yang secara personal menyukai sekolah mereka, diketahui memiliki sikap yang lebih baik dan lebih sehat secara fisik maupun mental (Papalia, Olds, \& Feldman, 2008). Meski pada kenyataannya, pendidikan di Indonesia menghadapi tantangan untuk menyediakan kualitas yang sama rata antar satu sekolah dengan sekolah lain. Terlebih adanya survei yang menyatakan bahwa kualitas pendidikan di Indonesia masih sangat rendah, berada pada ranking paling bawah di Asia dari total 12 negara (Sahin dan Mete, 2016).

Efikasi diri seorang anak berkembang melalui bimbingan dan peran kedua orangtua, kemudian dipengaruhi oleh saudara kandung, teman seusia, dan juga dipengaruhi oleh faktor peran dari orang dewasa lain dalam proses hidupnya. Peran kedua orangtua menjadi remaja, anak akan menghadapi masa labil yaitu

penting karena ayah dan ibu akan menjadi model bagi perilaku anak. Lisnawati (2018) dalam penelitiannya juga menjelaskan bahwa orangtua wajib ikut aktif dan selalu mengawasi namun tidak mengikat anak, orangtua harus menyediakan waktu khusus untuk anak serta mengamati hal yang berhubungan dengan masalah anak.

\section{Hubungan Pola Asuh Permisif terhadap Efikasi diri pada Anak}

Tabel 4 menunjukan ada hubungan pola asuh permisif orangtua terhadap efikasi diri pada anak. Nilai koefisien korelasi menunjukan arah korelasi negatif yang kuat $(r=-.845)$ dalam arti semakin orangtua menerapkan pola asuh permisif maka semakin rendah efikasi diri pada anak. Peneliti menilai hal tersebut dapat terjadi karena pola asuh yang diberikan oleh orangtua adalah pola asuh permisif dimana pola asuh ini memberikan kebebasan penuh pada anak dan membiarkan anak memonitor aktivitasnya sendiri. Orangtua melepas kontrol pada anak sehingga muncul efikasi diri yang rendah seperti ketidakstabilan emosi, tingkat depresi yang tinggi, serta anak menyatakan kesulitan untuk mengekspresikan emosi. Hasil penelitian ini sejalan dengan penelitian yang dilakukan oleh Ningrum (2019) terhadap 100 orang anak remaja menunjukan efikasi diri dengan kategori rendah lebih banyak (52 orang, 52\%) pada tipe pola asuh permisif orangtua.

Nurmalitasari (2015) menjelaskan bahwa pada pola asuh permisif, orangtua jarang atau bahkan tidak pernah memberikan penjelasan dan pengarahan terhadap tingkah laku anak, anak bingung dengan konsep perilaku yang salah dan benar sehingga dapat memunculkan timbulnya perilaku yang kurang percaya diri. Pengasuhan dengan pola permisif juga cenderung mengarah kepada penelantran atau pembiaran anak. Rendahnya bentuk dan proses interaksi yang terjadi antra orangtua dan anak pada pola asuh tipe ini juga menjadi penyebab rendahnya efikasi diri pada anak 
(Mulyadi, 2016). Diperlukan dukungan pola keluarga yang lain baik, untuk pembentukan efikasi diri yang positif pada anak. Dengan demikian, anak akan lebih terarah sembari meningkatkan kemandiriannya.

Pola asuh permisif memiliki kelebihan dibanding pola asuh lain, ditandai dengan tingginya tingkat responsivitas anak meski orangtua kurang memberikan tuntutan dan kontrol pada anak. Orangtua yang permisif tidak terlalu terlibat dengan anak, tidak menuntut ataupun mengkontrol anak. Orangtua membiarkan anak melakukan apa saja yang diinginkan, hanya membuat sedikit permintaan dan membiarkan anak memonitor aktivitas anak sendiri. Orangtua cenderung hangat, terbuka secara afeksi namun tidak memberikan batasan pada anak. Kekurangan pola asuh permisif mengakibatkan anak kurang mampu mengendalikan tingkah laku dan melakukan apapun yang ingin dilakukan. Anak juga mengalami kesulitan untuk menjalin relasi dengan lingkungan sosialnya. Dampak lain yang diterima anak adalah rendahnya kemampuan anak untuk berempati dengan orang lain (Laksmi dkk, 2018).

Berdasarkan teorinya, efikasi diri memiliki kaitan yang erat dengan pola pengasuhan orangtua, dimana awal pertumbuhan efikasi diri dipusatkan pada orangtua yang kemudian dipengaruhi oleh pengaruh saudara kandung, teman sebaya dan orang dewasa lainnya yang berada di sekitar lingkungan anak (Laksmi, 2018). Efikasi diri juga berkaitan erat dengan orangtua sebagai model sosial serta pendukung paling dekat dengan anak. Orangtua menjadi figur awal yang diamati dan akan ditiru oleh anak, efikasi diri yang tinggi dimiliki oleh anak yang memandang figur orangtuanya sebagai pendidik yang sukses dan memberikan dukungan yang baik hingga anak berhasil. Sebaliknya efikasi diri anak akan menurun jika figur yang diamati menunjukkan kegagalan, pesimis, bahkan kurang mendukung tujuan hidup dan cita-cita anak. Peningkatan efikasi diri dapat ditingkatkan asuh orangtua dan interaksi dengan anggota dengan pemilihan pola asuh yang tepat oleh orangtua. Beberapa faktor lain yang mempengaruhi efikasi anak selain pola asuh adalah budaya yang dianut oleh orang terdekat anak (Gulo, Barus dan Hawa, 2021) serta peran gender (Imro'ah, Winarso dan Baskoro, 2019) yang tidak diteliti dalam penelitian ini.

\section{KESIMPULAN}

Terdapat hubungan yang kuat namun berarah negatif antara pola asuh permisif orangtua terhadap efikasi diri pada anak usia sekolah dan remaja di Desa Landungsari RT 03/ RW 02 Kabupaten Malang. Hal ini bermakn penerapan pola asuh permisif oleh orangtua justru dapat menurunkan efikasi diri anak usia sekolah dan remaja.

Saran dan rekomendasi untuk penelitian selanjutnya adalah mengikutsertakan berbagai faktor lain baik dari sisi demografis, peran gender, serta budaya yang unik dalam hubungannya terhadap pola asuh orangtua dan efikasi diri anak usia sekolah dan remaja. Serta mengikuti perkembangan efikasi diri anak melalui pendekatan prospektif.

\section{REFERENSI}

Adicondro, N., \& Purnamasari, A. (2011). Efikasi diri, dukungan sosial keluarga dan self regulated learning pada siswa kelas VIII. Universitas Abmad Dablan.

Bandura, A, (2010). Self Efficacy Mechanism in Psikological and Health Promoting Behavior. Prentice Hall, New Jersy.

Bandura, A. (1994). Bandura Self-efficacy defined. Encyclopedia of Human Behavior. Retrieved from http://www.uky.edu/ eushe2/Bandu ra/BanEncy.html

Bandura, A. (2005). Self-Efficacy The Exercise of Control. New York: W. H. Freemanand Company.(Online) dalam (http://skripsipsikologie.wordpress.co $\mathrm{m} / 2010 / 07 / 05 /$ efikasi-diri-dan- 
Nursing News: Jurnal Ilmiah Keperawatan, Vol 5, No 2 Tahun 2021 ,hal 75-85

kecemasan/di akses pada 05 Februari 2021).

Baumrind, Diana (2011). Prototy Pical Descriptions of 3 Parenting Styles. (Online). Tersedia:

http://www.devpsy.org/teaching/par ent/Baumrind Parenting styles.pdf.

Baron, Robert, A., \& Byrne. D. (2012). Psikologi Sosial jilid 2. Jakarta: Erlangga

Dasmo, D., Nurhayati, N., \& Marhento, G. (2015). Pengaruh Tingkat Pendidikan dan Pola Asuh Orangtua Terhadap Prestasi Belajar IPA. Formatif: Jurnal Ilmiah Pendidikan MIPA, 2(2), 132-139. http://dx.doi.org/10.30998/formatif. v2i2.94

Kemenkes, R. I. (2018). Laporan Nasional Riskesdas 2018. Jakarta: Kemenkes RI, 154-166.

Erikson, E. H., Erikson, J. M., \& Kivnick, H. Q. (1994). Vital involvement in old age. WW Norton \& Company.

Farisi, H. A. (2020). Pengarub Deprivasi Relatif Pada Efikasi Diri Akademik Dengan Dukungan Sosial Pada Mahasiswa Di Perguruan Tinggi Sebagai Variabel Moderator Pada Mahasiswa Generasi Pertama (Doctoral dissertation, UNIVERSITAS AIRLANGGA).

Fakhruddin. (2011). Hubungan Pola Asub Orang Tuan dengan Perilaku Sosial Remaja di Desa Pnduman Kecamatan Jilbuk. Jember. Etheses.uin-malang.ac.id

Febrianti, R. E. (2012). Hubungan antara pola asub dan status ekonomi orang tua dengan hasil belajar ekonomi siswa (studi kasus pada siswa kelas VII SMP N 8 Malang) (Doctoral dissertation, Universitas Negeri Malang).

Feist, Jess dan Feist, J. Gregory (2008). Theories of Personality. Alih Bahasa
(2006). Santoso. Yogyakarta: Pustaka Pelajar.

Gunarsa, (2002) Psikologi perkembangan anak dan remaja, BPK Gudang Mulia. Jakarta.

Hadzic, R., Magee, C.A., and Robinson, L. (2013). "Parental Employment and Child Behaviors: Do Parenting Practices Underlie These Relationships?.'International Journal of Behavioral Development, 37 (4), 332-339. Online:http:// ro.uow.edu.au/ cgi/ viewcontent.cgi? article $=1302 \&$ context $=$ sspapers $)$. Diakses Pada 25 Februari 2021.

Hurlock, E.B. (2009). Psikologi Perkembangan. Suatu Pendekatan Sepanjang Rentang Kebidupan.Jakarta: Erlangga.

Irmawati. (2002). Motivasi Berprestasi \& Pola Pengasuban Pada Suku Bangsa Batak Toba \& Suku Bangsa Melayu (tesis). Jakarta: Fakultas Pasca UI.

Irsan, M. (2016). Pengaruh Efikasi Diri, Aktualisasi Diri, Perhatian Orang Tua, dan Motivasi Belajar terhadap Hasil Belajar Matematika Peserta Didik SMP se Kecamatan Tompobulu Kabupaten Bantaeng (Doctoral dissertation, Pascasarjana).

Jahja, Y. (2011). Psikologi perkembangan. Edisi Pertama. Jakarta : Penerbit Kencana.

Kurniawan, A. (2017). Pengarub Pola Asub Permisif Terhadap Rasa Percaya Diri Siswa Kelas V Sd Se-Gugus 1 Wates Kabupaten Kulon Progo. Skripsi: Universitas Negeri Yogyakarta, Fakultas Ilmu Pendidikan.

Laksmi, Putu Putri Dena, Suniasih, Ni Wayan, dan Komang Ngurah Wiyasa. (2018). Pengaruh pola asuh terhadap efikasi diri. Jurnal kesehatan dan pengembangan pendidikan Vol.2 (1). Online: https://www.researchgate.net/publica tion/331868323 Pengaruh Pola Asu 
Nursing News: Jurnal Ilmiah Keperawatan, Vol 5, No 2 Tahun 2021 ,hal 75-85

h Orang Tua terhadap Efikasi Diri. Diakses Pada 25 Februari 2021.

Lisnawati, L. (2018). Mewnjudkan Pendidikan Dalam Keluarga Muslim Yang Visioner. Muaddib: Studi Kependidikan dan Keislaman, 8(1), 77-89.

Luthans, B. C., Luthans, K. W., \& Chaffin, T. D. (2021). Character matters: The mediational impact of self-regulation on PsyCap and academic performance. Journal of Education for Business, 1-15.

Mahardikawati. (2012). Skripsi: bubungan antara self-efficacy dengan prestasi belajar siswa kelas VIII SMP Negeri 2 Sukaraja Kabupaten Sukabumi tabun ajaran 20112012.Bandung: Repository. Upi. Edu. [9 November 2012]

Mulyadi, A. S. (2016). Implementasi Terapi Keluarga Strategis Pada Keluarga Dengan Anak Yang Berbadapan Dengan Hukum Di Desa Sukamantri Kecamatan Paseb Kabupaten Bandung. Pekerjaan Sosial, 15(1).

Ningrum, Deci Cahya. (2019). Perbedaan Self Efficacy Remajaditinjau Dari Pola Asuh. Skripsi.

Nurhayanti, R., \& Novotasari, D. (2013). Tipe Pola Asuh Orang Tua yang berhubungan dengan Perilaku Bullying di SMA Kabupaten Semarang. Jurnal Keperawatan Jiwa, 1(1).

Nurmalitasari, F. (2015). Perkembangan Sosial Emosi Pada Anak Usia Prasekolah. Bulletin Psikologi. 23(2).

Nuruddin, Ilham. (2015). Hubungan antara efikasi diri dengan prokrastinasi akademi pada siswa MA Al-Hidayah Wajak Malang. Undergraduate thesis, Universitas Islam Negeri Maulana Malik Ibrahim Malang.
Papalia, D. E., Olds, S. W., \& Feldman, R. D. (2001). Physical and cognitive development in adolescence. Author, In human development, 406-443.

Papalia, D., Olds, S., \& Feldman, R. (2008). Human Growth and Development. New York: McGraw Hill.

Pemerintah Kota Malang, (2021). Upah Minimum Kota Malang 2017 Disosialisasikan. Available online: https://malangkota.go.id/2016/12/08 /upah-minimum-kota-malang-2017disosialisasikan/

Purwaningsih, E., \& Setyaningsih, R. T. (2015). Hubungan Pola Asuh Orang Tua Dengan Kejadian Pernikahan Usia Dini Di Desa Jambu Kidul, Ceper, Klaten. INVOLUSI Jurnal Ilmu Kebidanan, 4(7).

Sahin, S., \& Mete, J. (2016). Sustainable Development: Environmental, Economical, Social Well-Being for Today and Tomorrow. Mimbar Pendidikan, 1(1).

Santrock, J. W. (2002). Life-span development (development of the life span). Jakarta: Erlangga

Saraswati, A. Ratnaningsih, I. Z. (2016). Hubungan Antara Efikasi Diri Akademik Dengan Kematangan Karir Pada Siswa Kelas Xi Smk N 11 Semarang. Jurnal Empati. Vol 5 (3).

Soetjiningsih. (2004). Tumbuh kembang remaja dan permasalahannya. Jakarta : Sagung Seto.

Suharto, S., Japlani, A., \& Ali, K. (2021). Pengukuran Minat Berwirausaha Menggunakan Self Efficacy, Lingkungan Dan Pendidikan Kewirausahaan Pada Mahasiswa Feb Universitas Muhammadiyah Metro. Jurnal Bisnis Darmajaya, 7(1), 5269. 
Nursing News: Jurnal Ilmiah Keperawatan, Vol 5, No 2 Tahun 2021 ,hal 75-85

Widanarti, N. indati, A. (2002). Hubungan Antara Dukungan Sosial Keluarga Dengan Self Efficacy Pada remaja di SMA Negeri 9 Yogyakarta. Jurnal Psikologi 2 (2).

Wirawan. (2012). Menghadapi Stres dan Depresi (seni menikmati bidup agar bahagia). Jakarta: Platinum.

Yusuf, R. N. (2019). Hubungan Antara Pola Asuh Permisif Dengan Kepercayaan Diri Remaja Di Smp Negeri 35 Bandar Lampung (Doctoral dissertation, UIN Raden Intan Lampung).

YUSMAN, E. (2015). Hubungan Pola Asuhorangtua Dengan Prestasi Belajar Anak Sd Negeri 05 Pt Kelas 2 Dimeruya Selatan Jakarta Barat. Undergraduate these health of faculty Universitas Esa Unggul. Available online: https://digilib.esaunggul.ac.id/hubung an-pola-asuhorangtua-denganprestasibelajar-anak-sd-negeri-05-ptkelas-2-dimeruyaselatan-jakarta-barat5079.html 